\title{
KNOWLEDGE, ATTITUDE AND PRACTICES OF ADOLESCENT SECONDARY SCHOOL STUDENTS IN UVWIE LOCAL GOVERNMENT AREA OF DELTA STATE TO HIVIAIDS.
}

\author{
*E.A. TOBIN, *H.O. OKOJIE
}

\section{*DEPARTMENT. OF COMMUNITY HEALTH, UNIVERSITY OF BENIN TEACHING HOSPITAL}

\section{Corresponding author:}

Dr E. A. Tobin.

Email: ekatobin@yahoo.com,

Mobile: $+234(08) 37544369$

\begin{abstract}
INTRODUCTION: Adolescents have a tendency to engage in high risk sexual and drug-use behaviour; and with a poor health-seeking behaviour, they continue to present the highest number of new cases of HIV reported in Africa.
\end{abstract}

OBJECTIVE: To assess the knowledge, attitude and practise of adolescent secondary school students towards AIDS.

METHOD: A cross sectional study was carried out on 358 senior secondary students selected by multistage sampling. A researcher administered semi-structured questionnaire was used for data collection.

RESULTS: All had heard of AIDS, of which $40 \%$ cited the media as source of information. Seventy four percent knew the cause to be a virus, $63 \%$ could differentiate between AIDS and HIV, over $85 \%$ knew of transmission through sex, mother to child, contaminated blood, and contaminated needles; $59 \%$ cited kissing. Weight loss was the most common symptom (85\%) mentioned. Over $76 \%$ knew AIDS to be untreatable. Over $75 \%$ knew methods to prevent spread of which $23 \%$ cited sex with a virgin, $61 \%$ did not know anyone infected with the virus, $58 \%$ felt infected persons should not be allowed to stay in the community, $61 \%$ agreed to continue a relationship with an infected friend, $83 \%$ agreed to care for an infected relative. Of $22 \%$ who agreed they were sexually active, $66 \%$ and $12 \%$ had one and multiple partners respectively. Regarding protection, 30\% used condom always, $48 \%$ sometimes and $23 \%$ never. Twenty-one percent had ever had sex under influence of alcohol or marijuana. 55\% were willing to be tested, however none had been tested.

CONCLUSION: Senior secondary school students in Uvwie have a fairly good knowledge of AIDS, and poor attitude towards people living with AIDS. Few are sexually active and are engaged in unsafe sex.

KEYWORDS: AIDS, secondary school students, condom use, knowledge, HIV risk behaviour, sexual practices.

\section{INTRODUCTION}

The adolescent period is a time of vulnerability during which internal conflict caused by hormonal changes, the influence of peer group, and the attitude and practises of significant adults in their lives such as teachers and parents, societal pressure, norms and values and economic situations all 
contribute to mould the character and behavioural patterns that are carried onto adulthood ${ }^{1}$. They are a high-risk group, more likely to be engaged in risky sexual and drug- use behaviour, with reduced feelings of vulnerability to disease, and oftentimes, a denial of any chance of infection; and less likely to have adequate knowledge of AIDS or other sexually transmitted diseases. Unfortunately, with a poor health ï seeking behaviour, they are also less likely to seek medical help or counselling. Thus, they continue to present the highest number of new cases of HIV reported in Africa with about $50 \%$ or 7000 young people aged 15-24 years being infected each day, and globally 10 million people aged 13 -24 years infected in the last decade ${ }^{1,2}$.

The level of accurate knowledge adolescents have about the cause and nature of HIV/AIDS, the methods of spread and the preventive measures will greatly influence their attitude towards the disease entity itself and people living with it, as well as result in a change in their sexual behaviours in favour of abstinence or at least a lower practise of unsafe sex. This is evidenced from findings from a school based AIDS education programme carried out in a secondary school in Nigeria where 223 students who received a comprehensive health education intervention were compared with 217 controls. At post-test, intervention students exhibited significantly ( $p<$ 0.05) greater knowledge about HIV/AIDS transmission and prevention. Intervention students were less likely to feel AIDS is a white man's disease and were more likely to be tolerant of people living with the disease $(p<0.05)$. After the intervention, the mean number of reported sexual partners among those in the intervention group significantly decreased from 1.51 to 1.06 , while it increased from 1.3 to 1.39 among the controls. The study also reported an increase in consistent use of condom and the use of condom at last sexual intercourse among students in the intervention group ${ }^{3}$.

Unfortunately, research has shown that the depth of knowledge adolescents have about AIDS varies across the world. Even where there seems to be a high level of knowledge about AIDS, closer investigation will reveal that this knowledge is oftentimes incorrect, and most adolescents lack the skills and knowledge to protect them against AIDS $^{4,5}$.

In a study conducted among 300 Haitian adolescents aged 13- 18 years, it was found that overall knowledge about HIV/AIDS was high with the majority of adolescents identifying unprotected sex and sharing injection drug needles as HIV transmission routes. Moreover, approximately $75 \%$ of the adolescents reported condom use as an effective preventive strategy. However, misconceptions that could reduce adolescents' adoption of HIV preventive strategies were also identified such as the belief among a few that a cure exists, and doubts regarding the severity of the disease ${ }^{6}$. In Cambodia, $85-100 \%$ of young people have heard about AIDS; however $60.1 \%$ of the males and $37.7 \%$ of females had wrong notions about methods of spread 7 . In Mozambique, a study revealed that only $74 \%$ of girls and $62 \%$ of boys aged 15-19 knew about AIDS, but did not know of methods of protection against AIDS ${ }^{8}$. Among 896 adolescents aged 11 ï 25 years who participated in a study in Niger state, Nigeria, $91.9 \%$ had heard of AIDS, with knowledge of the disease ranging from $41.9 \%-63.8 \% 9$. A healthy 
attitude towards AIDS has been documented in students that have knowledge of HIV and AIDS ${ }^{10}$. A study among 600 adolescent secondary school students in Benin, found that, $88 \%$ had heard about AIDS, and showed positive attitudes towards HIV/AIDS campaign strategies ${ }^{11}$.

In a study undertaken to assess the knowledge, attitude and practise of secondary school students towards AIDS in Barbados, of the 1048 students surveyed, only $31.1 \%$ used condoms consistently during sexual activity, while $45.8 \%$ and $17.1 \%$ used condoms óoccasionallyô and óneverô respectively despite a high awareness of the disease ${ }^{12}$.

\section{METHODOLOGY}

The study was carried out in Uvwie Local Government area, one of 25 other local government areas that make up Delta state in Nigeria. The local government area is divided into 4 quarters and has as headquarters Effurun. It occupies a land area of 95.1570 square kilometres, and is bounded by Udu local government on the north, Ororokpe local government on the south and Warri local government on the east and west. The region is predominantly occupied by the Uvwie people, and the main language is Urhobo. The people are predominantly farmers, but are also employed in a wide variety of whiteand blue- collar jobs. There are about 5 government health centres in the area, and about 15 private health facilities. The local government is home to 7 government secondary schools and several private secondary schools.

A descriptive cross sectional study design was used.

Study population was made up of male and female adolescents enrolled in the most senior secondary class
(SSIII) of both private and government owned day schools within the local government.

A sample size of 358 was calculated using the appropriate formula for a descriptive study with prevalence taken as $70 \%$ from a previous study and an attrition rate of $10 \%{ }^{10}$.

Respondents were selected by multistage sampling. Using a list of 30 accredited government and private secondary schools in the local government, 2 government and 5 private schools were selected by random sampling. In the selected schools, respondents were chosen by systematic sampling from the class list, after they had been stratified by sex. Informed consent was obtained from the participants, and permission to carry out the study was obtained from the principals of the schools.

Data was collected by using a researcher administered structured English language questionnaire focusing on knowledge and attitudes towards AIDS and sexual practises of the students. Analysis of data was with SPSS version 16. Continuous variable (such as age) were presented as means and standard deviation. Categorical variables were analysed using chi-square or the exact test where appropriate with level of significance set as $p<0.05$.

\section{RESULTS}

Three hundred and fifty eight students participated in the study with $183(51.1 \%)$ males and 175 (48.9\%) females. Mean age of female students was $15.7 \pm 2.6$ years, and of males, $15.5 \pm 1.8$ years. Two hundred and ninety-seven (83\%) were from a monogamous family, and all respondents were of the Christian faith. Table 1. 
All had heard of AIDS. Two hundred and ninety-four (82\%) knew what the acronym AIDS stands for. Three hundred and two (84.43\%) knew the cause to be a virus, $30(8.38 \%)$ a bacteria, $9(2.4 \%)$ a curse from God and $17(4.79 \%)$ were ignorant of the cause.

Two hundred and twenty-six (63\%) could differentiate between AIDS and HIV. Over $85 \%$ knew of transmission through sex, mother to child, contaminated blood, and contaminated needles. Two hundred and eleven (59\%) and 183 (51\%) wrongly cited kissing and insect bite as modes of transmission. Table 2.

While 350 (98\%) were sure of blood as a media of spread, 124 (34.64\%), 106 (29.61\%) and 104 $(29.05 \%)$ were not sure of urine, saliva and sweat respectively. Table 3.

As regards knowledge of common symptoms, 304 (85\%) mentioned weight loss, with 171 (48\%) and $150(42 \%)$ mentioning diarrhoea of more than one monthês duration and atypical rash respectively.

Two hundred and seventy-two (76\%) knew AIDS to be untreatable, while $179(50 \%)$ knew drugs could reduce mother to child transmission.

Over $75 \%$ knew prevention of AIDS through safe blood transfusion, use of disposable needles, use of condom during sex, avoidance of homosexuality, or sex with multiple partners while $82(23 \%)$ wrongly citing sex with a virgin. Only $230(64.2 \%)$ mentioned abstinence. Table 4.

Sixty-one percent did not know anyone infected with the virus.

The television was the principal source of AIDS information to $40 \%$ of respondents. Figure 1.

Two hundred and nine (58.4\%) felt infected persons should not be allowed to stay in the community, $218(60.9 \%)$ agreed to continue a relationship with an infected friend. Two hundred and ten $(59 \%)$ felt there was no need to care for infected patients while 296 $(82.7 \%)$ agreed to care for an infected relative. Table 5 .

Of $79(22 \%)$ respondents who agreed they were sexually active, 52 $(66 \%), 17(22 \%)$ and $10(12 \%)$ had one, two and multiple partners respectively. Mean age at first intercourse was 12.8 \pm 9.8 years for males, and $15.3 \pm 4.3$ years for females. Regarding protection, 24 (30\%) used condom with each sexual encounter, 38(48\%) sometimes, and 17 (22\%) never.

Sixteen $(21 \%)$ of the sexually active had ever had sex under influence of alcohol or marijuana while $50(63 \%)$ had been refused sex before due to unavailability of a condom.

Three hundred and seven (86\%) were not in favour of unprotected premarital sex.

Of all 358 respondents, 272 (76\%) were against extra-marital relationships, 307 $(86 \%)$ were against pre-marital sexual relationships and 262 (73.1) felt at risk of contacting AIDS if they engaged in unprotected intercourse.

Two hundred and nine (75\%) were willing to disclose their status if tested positive for the virus, 197 (55\%) were willing to be tested, however none had ever been tested

\section{DISCUSSION}

While knowledge of HIV transmission risks alone may not be sufficient to prevent risky behaviours among adolescents, correct information regarding the HIV virus and its transmission is still a necessary prerequisite for risk reduction. Therefore, assessment of HIV knowledge within this specific at-risk population is without doubt an important step toward informing future prevention programs ${ }^{6}$. From the study, awareness and indeed general 
knowledge about the AIDS virus, modes of transmission and prevention of the disease were good, although with some misconceptions, such as slightly less than half of the students citing kissing as a mode of transmission. While some studies have similarly reported good knowledge ${ }^{6,13}$, others have shown adolescent students to have gaps in their knowledge of the disease in spite of a high level of awareness ${ }^{14,15}$. In this study, the mass media was largely the source of information for the students, a finding consistent with what has been documented in other studies ${ }^{16,17}$. However, the deficiencies in knowledge show the inadequacies of the mass media to provide correct information about the disease. The lesser role of parents and teachers highlights the need for school based AIDS education programmes involving both parents and teachers in the spread of AIDS information. The attitude toward AIDS and PLWHA was generally poor except when close relations were affected. This is comparable to what was reported in other studies ${ }^{13}$. This finding might be due to the fact that adequate emphasis may not have been paid to removing the stigma associated with the disease, and might in fact be a reflection of the attitude of other members of the community to the disease and those affected. This is also reflected in the unwillingness of a large proportion of students to be tested for the disease. Overall, sexual activity was found to be low (22\%), but significant enough to cause concern, as a greater proportion of the sexually active practiced unsafe sex. The level of sexual activity among students in this study is less than what was found in a study carried out among secondary school students in Ilesha, Nigeria, where it was documented to be $50 \%{ }^{18}$. This unsafe sexual behaviour puts them at a great risk of acquiring sexually transmitted infections including HIV infection.

CONCLUSION: Senior secondary school students in Uviwe had good knowledge of AIDS, and poor attitude towards people living with AIDS. Few are sexually active and largely engaged in unsafe sex. It is necessary that HIV information and life skill education be intensified through school based education programs, as part of school curriculum, and through community activities involving parents and faith based organisations. Such information should also aim to correct the negative attitude towards people affected by the disease. There is need for the introduction of reproductive health programmes that will target a positive change in adolescentsô attitudes to risky sexual behaviours and motivate them to undertake behaviours that would limit such risks. Youth friendly health services that will provide HIV counselling and testing should be established within the communities.

\section{REFERENCES}

1. Fernadez DM, Figueroa WI, Gomez M, Maysonet J, Olivares ER, Hunter RF. Changes in HIV/AIDS knowledge among early adolescents in Puerto Rico. Ethnicity and Disease. 2008; 18(2): $146-150$

2. World Health Organisation (WHO), 2002. Child and adolescent health and development. HIV/AIDS and adolescents. Retrieved January 21, 2004 from the World Wide Web: 
http://www.ho.int/childadolescent-

health/HIV/HIV adolescent

3. Fawole IO, Asuzu MC, Oduntan SO, Brieger WR. A school based AIDS education programme for secondary school students in Nigeria: a review of effectiveness. Health Educ Res. 1999; 14 (5): 675 ï 83

4. Oyo-Ita AE, Ikpeme BM, Etokidem J, Offor JB, Okokon EO, Etuk SJ. Knowledge of HIV/AIDS among secondary school adolescents in Calabar, Nigeria. Annals Afr Med. 2005; 4(1): 2-6

5. Salehi L, Shakibazadeh E, Farkhondeh S. A population based survey of HIV/ AIDS knowledge and attitude in general public , Bandar-Abbas, Iran. Pak J Med Sci. 2008; 24(6): 838-44

6. Marcelin LH, McCoy HV, Didemente RJ. HIV/AIDS knowledge and beliefs among Haitian adolescents in MiamiDade county, Florida. J HIV AIDS Prev Child Youth. 2006; $7(1): 121-38$

7. UNESCO . Knowledge attitude and behaviour of adolescent reproductive and sexual health: regional profile. 2002. [ cited 2004 January 20]. Available at : http://www.unescobkk.org/ips/ar $\underline{h-}$

web/demographics/demosub2.c $\underline{f m}$

8. Sexuality Information and Education Council of the United States (2001, February, 23).
Teachersô knowledge and attitudes towards HIV/AIDS education. School Health Opportunities and Progress Bulletin, 2001, 5, 25. [cited 2004 January 22]. Available at:

http://www.the

body.com/siecus/teacher_knowl edge.html

9. Sumola MA, Dipeolu M, Babalola S, Adebayo DO. Reproductive knowledge, sexual behaviour and contraceptive use among adolescents in Niger State, Nigeria. Afr J Reprod Health. 2003; 7(1): 37 ï 48

10. Lau JTF, Lee SS. Evaluation of educational program on AIDS in secondary schools in Hong Kong. Proceedings of the 10th International AIDS conference, August 7-12, 1994. Yokohama, Japan. [Cited 2004 January 22]. Available at: $h$ ttp://www.csu.med. cuhk.edu.hk/hkaids/crp/l.htm.

11. Imogie $\mathrm{AO}$, Iweze $\mathrm{F}$, Egbochuku EO. The perceived knowledge and awareness of HIV/AIDS by secondary school students in Benin city, Nigeria. West African Journal of Nursing. 2002; 13(1): 12-16

12. Division of Youth Affairs. Report on the National knowledge, attitude, beliefs and practises survey on HIV/AIDS. Ministry of education, youth affairs and sports, Barbados.2001 [cited 2004 January 21]. Available at: http://www.hivids.gov.bb/aidsinfo/KAPB\%20Ai ds\%20Report.pdf. 
13. Brook U. AIDS-related knowledge and attitude among high school students in Holon Israel. J Trop Pediatr. 1993; 39 (6): 382 ï 84

14. Lal SS, Vasan S, Sarma SP, Thankappan KR. Knowledge and attitude of college students in Kerala towards HIV/AIDS, sexually transmitted disease and sexuality. Natl Med J India. 2000; 13: 231-6

15. Jaiswal S, Magar BS, Thakali K, Pradhan A, Gurubacharya DL. HIV/AIDS and STI related knowledge, attitude and practice among high school students in Kathmandu valley. Kathmandu University Med J. 2005; 3(1): 69-75

16. Lal P, Nath A, Badhan S, Ingle GK. A study of awareness about HIV/AIDS among senior secondary school children of Delhi. Indian J Community Med. 2008; 33(3): $190-92$
17. Ghabili K, Shoja MM, Kamran $P$. The Iranian female high school studentsô attitude towards people with HIV/AIDS: a cross-sectional study. AIDS Res Therapy. 2008; 5(1): 5-15

18. Orji EO, Esimai OA. Sexual behaviour and contraceptive use among secondary school students in Ilesha, South-West Nigeria. J obstetrics Gynaecology. 2005; 25(3): 26972 
Table 1: $\quad$ Sociodemographic variables of respondents

\begin{tabular}{lr}
\multicolumn{1}{c}{ Variable } & Frequency (\%) \\
\hline Age of respondents(years) & \\
$14-15$ & $85(23.7)$ \\
$16-17$ & $169(47.2)$ \\
$18-19$ & $86(24.0)$ \\
$20-21$ & $10(2.8)$ \\
$22-23$ & $6(1.7)$ \\
$24-25$ & $2(0.6)$ \\
& \\
\hline Sex distribution of respondents & $175(48.9)$ \\
Male & $183(51.1)$ \\
Female & \\
\hline Religion & \\
Christianity & $358(100)$
\end{tabular}

Table 2: $\quad$ Knowledge of mode of transmission of HIV among respondents $(\mathrm{n}=$ 358)

\begin{tabular}{|c|c|c|}
\hline Mode of transmission & $\begin{array}{c}\text { Correct } \\
\text { Responses } \\
\text { n ( \%) }\end{array}$ & $\begin{array}{c}\text { Incorrect } \\
\text { Responses } \\
\text { n ( \%) }\end{array}$ \\
\hline Sexual intercourse & $323(90.2)$ & $35(9.8)$ \\
\hline Transfusion with infected blood & $321(89.7)$ & 37 (10.3) \\
\hline Infected needles & $325(90.8)$ & $33(9.2)$ \\
\hline Pregnant mother to child & $290(81.0)$ & $68(19.0)$ \\
\hline Sharing clothes with infected persons & $283(79.0)$ & $75(21.0)$ \\
\hline Shaking hands with infected persons & $299(83.6)$ & $59(16.4)$ \\
\hline Using same toilet with infected persons & $282(78.7)$ & $76(21.3)$ \\
\hline Bite from an infected person & $175(48.8)$ & $183(51.2)$ \\
\hline Drinking from same glass & $254(70.9)$ & $104(29.1)$ \\
\hline Insect bite & $239(66.7)$ & 119 (33.3) \\
\hline
\end{tabular}


Table 3: $\quad$ Respondents' knowledge of media of transmission of HIV ( $n=358)$

\begin{tabular}{|lcc|c|c|}
\multicolumn{1}{c}{ Medium } & $\begin{array}{c}\text { Yes } \\
\mathbf{n}(\%)\end{array}$ & $\begin{array}{c}\text { No } \\
\mathbf{n}(\%)\end{array}$ & $\begin{array}{c}\text { Don't know } \\
\mathbf{n}(\%)\end{array}$ & $\begin{array}{c}\text { Not sure } \\
\mathbf{n}(\%)\end{array}$ \\
\hline BLOOD & $351(98.0)^{*}$ & $0(0.00)$ & $4(1.12)$ & $3(0.88)$ \\
\hline SEMEN & $237(66.30)^{*}$ & $32(8.91)$ & $28(7.80)$ & $61(16.90)$ \\
\hline TEARS & $6(1.68)$ & $274(76.54)^{*}$ & $14(3.91)$ & $64(17.87)$ \\
\hline URINE & $44(12.29)$ & $172(48.04)^{*}$ & $18(5.03)$ & $124(34.64)$ \\
\hline SWEAT & $14(3.91)$ & $230(64.25)^{*}$ & $10(2.79)$ & $104(29.05)$ \\
\hline SALIVA & $94(26.26)$ & $150(41.90)^{*}$ & $8(2.23)$ & $106(29.61)$ \\
\hline
\end{tabular}

${ }^{*}$ Correct response.

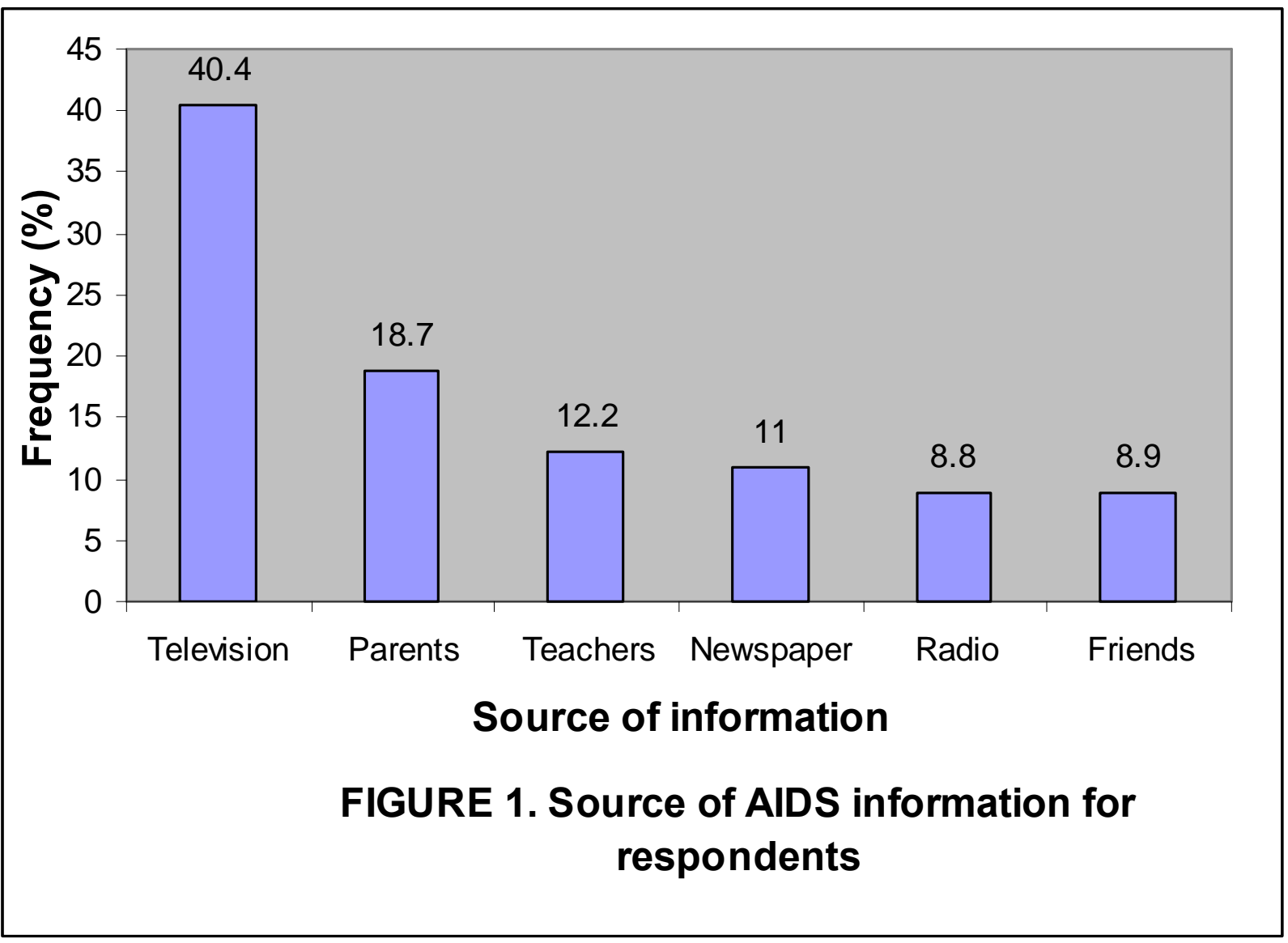


Table 4: Respondentsôknowledge of method of prevention of infection $(n=358)$

\begin{tabular}{|c|c|c|c|}
\hline Method & $\begin{array}{l}\text { Yes } \\
\text { n (\%) }\end{array}$ & $\begin{array}{c}\text { No } \\
\text { n (\%) }\end{array}$ & $\begin{array}{c}\text { Not sure } \\
\text { n (\%) }\end{array}$ \\
\hline Using condom during sex & $268(74.86)^{*}$ & $24(6.70)$ & $66(18.48)$ \\
\hline Avoid sex with multiple partners & $306(85.47)^{*}$ & $22(6.15)$ & $30(8.38)$ \\
\hline Avoid homosexuality & $216(60.34)^{*}$ & $42(11.73)$ & $143(39.93)$ \\
\hline No sex with prostitutes & $276(77.09)^{*}$ & $24(6.70)$ & $58(16.2)$ \\
\hline Safe blood transfusion & $302(84.48)^{*}$ & $16(4.60)$ & $39(10.92)$ \\
\hline Use disposable needles only & $266(74.30)^{*}$ & $52(14.53)$ & $40(11.17)$ \\
\hline Abstinence & $230(64.25)^{*}$ & $36(10.06)$ & $36(10.06)$ \\
\hline Sex with a virgin & $82(22.91)$ & $176(49.16)^{*}$ & $100(27.93)$ \\
\hline Avoid alcohol/marijuana & $20(5.59)^{*}$ & $232(64.80)$ & $106(29.61)$ \\
\hline
\end{tabular}

${ }^{*}$ Correct response.

Table 5: $\quad$ Attitude of respondents towards HIV/AIDS and aids PLWHA ( $n=358)$

\begin{tabular}{|c|c|c|c|}
\hline Attitude & Agree & Disagree & Uncertain \\
\hline $\begin{array}{l}\text { Being around someone with AIDS will } \\
\text { not put my health in danger }\end{array}$ & 236 (65.92)ã & $60(16.76)$ & $62(17.32)$ \\
\hline $\begin{array}{l}\text { Persons affected should not be allowed } \\
\text { to stay in the community }\end{array}$ & 209 (58.38) & 110 (30.73) ã & $39(10.89)$ \\
\hline $\begin{array}{l}\text { If one of my friends had AIDS, I shall } \\
\text { continue my normal relationship }\end{array}$ & 218 (60.89) ã & $64(17.88)$ & 76 (21.23) \\
\hline $\begin{array}{l}\text { Knowing there is no cure for AIDS, there } \\
\text { is no point in caring for AIDS patients }\end{array}$ & $210(58.66)$ & 90 (25.14) ã & $58(16.20)$ \\
\hline $\begin{array}{l}\text { If one of my family members gets AIDS, } \\
\text { I will be ready to care for him/her }\end{array}$ & 296 (82.68) ã & $36(10.06)$ & $26(7.26)$ \\
\hline
\end{tabular}

ã Positive attitude 